\title{
Clinical Outcomes of Non-variceal Upper Gastrointestinal Bleeding and its Relation to Aspirin and Anticoagulants
}

\author{
Hend Radwan ${ }^{1 *}$, Ehab Elsayed ${ }^{1}$, Hesham Alshabrawi ${ }^{2}$ \\ ${ }^{1}$ Department of Internal Medicine, National Research Center, Cairo, Egypt; ${ }^{2}$ Department of Internal Medicine, Ahmed Maher \\ Teaching Hospital, Cairo, Egypt
}

Edited by: Ksenija Bogoeva-Kostovsk Citation: Radwan $H$, Eysayed E Alshabrawi $H$. Clinica Outcomes of Non-variceal Upper Gastrointestinal Bleeding and its Relation to Aspirin and Anticoagulants. Open Access Maced J Med Sci. 2020 Feb 05; 8(B):11-19. ttps://doi.org/10.3889/oamjms.2020.3222 Keywords: Non-variceal upper gastrointestinal bleeding; Anticoagulants; Antiplatele
*Correspondence: Hend Radwan, Department of Internal Medicine, National Research Center, Cairo, Egypt. E-mail: hend.amin@outlook.com Received: 15-Jun-2019 Revised: 20-Oct-2019 Accepted: $02-\mathrm{Feb}-2020$

Copyright: @ 2020 Hend Radwan, Ehab Elsayed Hesham Alshabraw

Funding: This research did not receive an financial support Competing Interests: The authors have declared that no competing interests exist Open Access: This is an open-acess antisle distributed under the ter.

\begin{abstract}
BACKGROUND: Non-variceal upper gastrointestinal bleeding (NVUGIB) is a life-threatening emergency that requires an urgent management. Antiplatelet (e.g., aspirin) and anticoagulant drugs are widely chronically used in various cardiac and coronary artery diseases. These drugs increase the risk of NVUGIB as they may cause ulceration of the upper gastrointestinal $(\mathrm{GI})$ mucosa directly or may cause bleeding or rebleeding. The management of NVUGIB is complicated as the risk between GI bleeding episodes and cardiovascular attacks needs to be well managed.

AIM: The aim of this study is to determine the impact of antiplatelets (aspirin) and anticoagulants use on the morbidity mortality, and clinical outcomes in patients presented with non-variceal GI bleeding.

PATIENTS AND METHODS: A total of 105 patients presented with melena and/or hematemesis and diagnosed by upper $\mathrm{Gl}$ endoscopy were enrolled in a prospective cohort study. Patients were sub-grouped according to their use of antiplatelets, anticoagulants, or none (controls). Patients were excluded if they had portal hypertension or nonsteroidal anti-inflammatory drugs (NSAIDs) use and divided into five groups: Group I - patients who had not taken anticoagulants and antiplatelet; Group II - patients on heparin, warfarin, and LMWH only; Group III - patients on aspirin only; Group IV - patients on clopidogrel and ticlopidine with or without aspirin; and Group V - patients on combined anticoagulants and antiplatelet. All patients were subjected to clinical, laboratory (complete blood count, liver function tests, renal function tests, prothrombin time, and partial thromboplastin time), and endoscopic investigations. Clinical details were reported including admission, blood transfusion, rebleeding, and mortality.

RESULTS: Full medical history revealed that 43 patients were diabetic, 45 patients were cardiac, and 67 patients were hypertensive. Regarding the history of analgesic drug intake, 38 patients used NSAIDs and 29 of them used non-selective NSAIDs and 8 patients used selective NSAIDs. There were non-significant differences among the studied groups with NVUGIB regarding sex, hematemesis only presentation, melena only presentation, liver function tests, and endoscopic findings. On the other hand, there were statistically significant differences between the studied groups with NVGIB regarding increasing age, NSAIDs use whatever selective or non-selective, decrease level of HB, WBCs, serum albumin, bleeding profile, kidney function tests, clinical presentation in the form of hematemesis and melena, need for blood transfusion, history of associated diseases, especially being cardiac patients, rebleeding after 6 and 12 months, and mortality.
\end{abstract}

CONCLUSION: Aspirin intake may be associated with less favorable clinical outcomes in patients with NVUGIB while combined anticoagulants and antiplatelets seem to be associated with the worse outcomes.

\section{Introduction}

Non-variceal upper gastrointestinal bleeding (NVUGIB) is a critical clinical condition that requires an urgent management [1], [2]. It remains a clinically important due to the increase in the proportion of elderly population, use of nonsteroidal anti-inflammatory drugs (NSAIDs) [3].

The incidence of upper gastrointestinal bleeding (UGIB) is 2-fold greater in males than in females, in all age groups; however, the death rate is similar in both sexes [4].

The initial laboratory tests include a blood count international normalized ratio, partial thromboplastin time, electrolytes, creatinine, and blood typing in case transfusion is necessary [5].

\section{Management of NVUGIB (Figure 1) [6]}

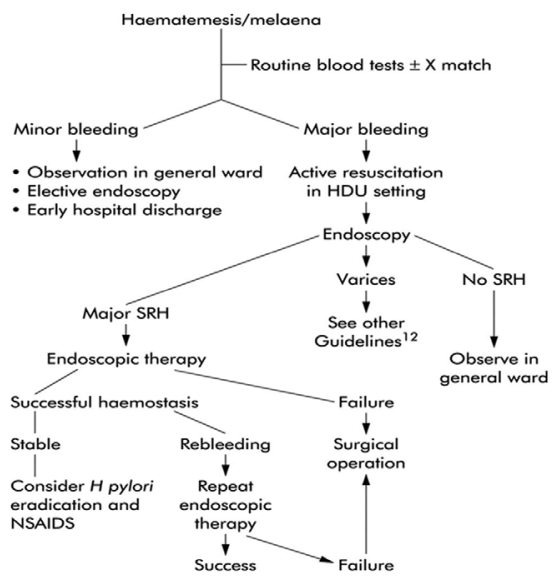

Figure 1: Algorithm for the management of acute gastrointestinal hemorrhage. HDU: High dependency unit, NSAIDs: Nonsteroidal anti-inflammatory drugs, SRH: Stigmata of recent hemorrhage (NICE Clinical Guideline, 2015) [6] 


\section{Resuscitation}

The first priority is to correct fluid losses and restore blood pressure. Thus, intravenous (IV) access is a must [7].

\section{Blood transfusion}

The timing and amount of blood transfusions are valuable. It is accepted that patients with a hemoglobin level of $\leq 7 \mathrm{~g} / \mathrm{dL}$ should receive a transfusion, whereas it is rarely indicated in patients with a hemoglobin level of $\geq 10 \mathrm{~g} / \mathrm{dL}$ [8].

\section{Pre-endoscopic care}

Recent consensus suggests that nasogastric lavage is not helpful for diagnosis, prognosis [9], [10]. Pre-endoscopic use of proton-pump inhibitors (PPIs) is highly important [11].

\section{Endoscopy}

It is the principle diagnostic tool in UGIB and hemostatic therapy. While diagnostic endoscopy in clinically stable patients without relevant comorbidity is safe, complications may occur [9].

There are various endoscopic techniques: injection with epinephrine; clip application; thermocoagulation, argon plasma coagulation or injection with alcohol; fibrin; or thrombin glue [12].

The combination of epinephrine injection with one of the above-mentioned therapies significantly reduces rebleeding, need for surgery, and mortality [13].

Second look endoscopy has to be outweighed with potential risks [8]. On the contrary, another cost-effectiveness study [14] found endoscopy is more effective and less expensive.

The highest risk for rebleeding in patients treated with a combination of endoscopic and PPI therapy is within the first $72 \mathrm{~h}$ after the initial bleeding episode $[15,16]$

\section{Medical therapy after endoscopy}

IV bolus followed by infusion of high-dose PPI reduces recurrent bleeding, need for repeated endoscopy, surgery, and blood transfusion [17], [18]. However, in patients with lower risk standard, PPI therapy (e.g., oral PPI once daily) is enough [19].

\section{Other considerations}

Surgery offers a better chance to secure hemostasis [20]. Angiographic embolization should be considered as an alternative to surgery [21].

\section{Helicobacter pylori}

The successful eradication of an associated $H$. pylori infection lowers the risk of reappearance of an ulcer in the $1^{\text {st }}$ year after hemorrhage to <5\% [22].

It is well known that $H$. pylori testing might reveal false-negative results in the setting of an acute bleeding episode [23].

\section{NSAID use}

In patients with NSAID-associated bleeding ulcers, the need for NSAIDs should be carefully assessed. In patients who must continue on NSAIDs, a cyclooxygenase-2 selective NSAID plus PPI offers the best available upper gastrointestinal (GI) protection [24], [25], [26].

\section{NVUGIB and antiplatelet and antithrombotic}

Nowadays, many patients receive chronic antithrombotic therapy for various cardiac diseases (Figure 2) [27].

\begin{tabular}{|ll|}
\hline Nonvariceal bleeding (80\%) & Portal hypertensive bleeding (20\%) \\
\hline Peptic ulcer disease (30-50) & Gastroesophageal varices $(>90)$ \\
Mallory-Weiss tears (15-20) & Hypertensive portal gastropathy ( $<5)$ \\
Gastritis or duodenitis (10-15) & Isolated gastric varices (rare) \\
Esophagitis (5-10) & \\
Arteriovenous malformations (5) & \\
Tumors (2) & \\
Others (5) & \\
\hline Adapted from Ferguson CB, Mitchell RM. Nonvariceal upper \\
gastrointestinal bleeding: Standard and new treatment. Gastroenterol \\
Clin North Am 2005:34:607-21. GI:Gastrointestinal \\
\hline
\end{tabular}

Figure 2: Causes of non-variceal upper gastrointestinal bleeding

The relative risk for UGIB increases up to $10 \%$ in patients treated with these therapies [28], [29], [30]. This complication puts affected patients into an acutely life-threatening situation because the mortality from UGIB ranges from $1 \%$ to $13 \%$ [31], [32], [33]. Therefore, therapy with ASA or clopidogrel in patients with cardiovascular risk factors should be restarted as soon as possible [8].

Anticoagulant therapy has historically consisted of heparins for the treatment of acute thrombosis and Vitamin Kantagonists (VKA) for long-term treatment [34].

VKAs are indicated in patients with atrial fibrillation, thromboembolic venous disease, or a mechanical heart valve, while, recently, the novel oral anticoagulants, such as dabigatran, rivaroxaban, and apixaban, have been used in non-valvular atrial fibrillation and venous thromboembolism [35].

The indications of antiplatelet drugs use are in the management of thrombotic diseases include stroke, acute myocardial infarction, acute coronary syndrome, and angina [36].

Clopidogrel requires cytochrome P450 isoenzyme CYP2C19 to be converted to its active metabolite [37]. PPI and clopidogrel compete for the same cytochrome P450 isoenzyme [38], [39], [40], [41], [42], but other studies did not reveal an increase in cardiovascular events [42], [43]. 
In the current study, we aim to determine the impact of antiplatelets and anticoagulants on the morbidity, mortality, and clinical outcomes in patients presented with non-variceal GI bleeding.

\section{Patients and Method}

This study included 105 patients admitted in Ain Shams University Hospitals and Ahmed Maher Teaching Hospital whom presented with hematemesis and/or melena and diagnosed by upper GI endoscopy and divided into five groups according to the drug intake.

Group I: Patients who had not taken anticoagulants and antiplatelet.

Group II: Patients on anticoagulants (heparin, warfarin, and low-molecular-weight heparin [LMWH] only).

Group III: Patients on aspirin only.

Group IV: Patients on clopidogrel and ticlopidine with or without aspirin.

Group V: Patients on combined anticoagulants and antiplatelet.

Patients were excluded if there were other causes of UGIB (esophageal varices, portal hypertensive gastropathy, and gastric varices if the bleeding source was gastric cancer, if bleeding was associated with endoscopic procedures such as endoscopic mucosal resection, or if bleeding occurred in the lower GI tract).

\section{Methods}

A written consent was taken from all participants and oral explanation of the whole procedure, in which they will be involved in. A full history taking including age-associated medical conditions as diabetes mellitus, cardiac, hypertension, gender, history of drug intake (NSAID) and antithrombotic drugs, and history of any inserted cardiac prostheses that might be a causal relationship to the hemorrhage (coronary stents and platelet aggregation inhibitors, cardiac valvular prostheses and anticoagulants, and aortic prostheses with the risk of an aortointestinal fistula). Full examination and full laboratories were done, including complete blood count, liver function tests (alanine aminotransferase [ALT], aspartate aminotransferase [AST], serum albumin, and total and direct bilirubin), renal function tests (serum creatinine and blood urea), and prothrombin time and partial thromboplastin time. Upper endoscopy was done by expert (one expert in each hospital to decrease the bias) endoscopists using fiber-optic endoscopy after good sterilization. Initial assessment and resuscitation according to the amount of bleeding (mild-moderate-massive), urgently or within 24-48 h (all patients were intravenously administered PPIs) was performed. Then, follow-up of our studied patients for rebleeding and mortality after 6 and 12 months after discharge from the hospital was done.

\section{Statistical analysis}

The collected data were tabulated and statistically analyzed using SPSS software (Statistical Package for the Social Sciences, version 16, SPSS Inc., Chicago, IL, USA). For quantitative data, the range, mean, and standard deviation were calculated. For qualitative data, the comparison between two groups was done by Chisquare test. For comparison between more than two means of data, $F$ value of ANOVA test was calculated. Significance was at $p<0.05$ for the results of the tests of significance.

\section{Results}

The study included 105 patients who were divided into five groups: Group I: Thirty patients (14 men [46.6\%] and 16 women [53.3\%]) who had not taken anticoagulants and antiplatelet, their mean age of $44.56 \pm 7.63$. Group II: Twenty patients on heparin, warfarin, and LMWH only. They were 8 males $(40 \%)$ and 12 females $(60 \%)$ with their mean age of 45.72 \pm 6.84. Group III: Twenty-five patients on aspirin only who were 12 men (48\%) and 13 women (52\%) with a mean age of $53.50 \pm 5.39$. Group IV: Fifteen patients (9 men [60\%] and 6 men [40\%]) on clopidogrel and ticlopidine with or without aspirin with a mean age of $55.19 \pm 6.47$. Group V: Fifteen patients 10 male $(66.6 \%)$ and 5 female $(33.3 \%)$ who were on combined anticoagulants and antiplatelet with their mean age of $56.46 \pm 7.35$ (Table 1).

Table 1: Demographic findings of the studied patients

\begin{tabular}{|c|c|c|c|c|c|c|}
\hline $\begin{array}{l}\text { Group } \\
\text { number }\end{array}$ & I (30) & II (20) & III (25) & IV (15) & $\mathrm{V}(15)$ & $p$ value \\
\hline $\begin{array}{l}\text { Age } \\
(\text { mean } \pm S D)\end{array}$ & $44.56 \pm 7.63$ & $45.72 \pm 6.84$ & $53.50 \pm 5.39$ & $55.19 \pm 6.47$ & $56.46 \pm 7.35$ & 0.000 \\
\hline \multicolumn{7}{|l|}{ Sex } \\
\hline $\begin{array}{l}\text { Male } \\
n(\%)\end{array}$ & 14 (46.66\%) & $8(40 \%)$ & $12(48 \%)$ & $9(60 \%)$ & $10(66.66 \%)$ & 0.519 \\
\hline $\begin{array}{l}\text { Female } \\
\mathrm{n}(\%)\end{array}$ & $16(53.33 \%)$ & $12(60 \%)$ & $13(52 \%)$ & $6(40 \%)$ & $5(33.33 \%)$ & \\
\hline
\end{tabular}

The study revealed that the sex among the studied groups was not statistically significant ( $p=0.519)$. Age of the patients was statistically significant $(p=0.000)$, as shown in Table 1 .

According to the laboratory profile of the studied patient groups, all were statistically significant except for ALT, AST, PLT, and total bilirubin which were statistically insignificant, as shown in Table 2. 
Table 2: Biochemical results of our studied patients

\begin{tabular}{|c|c|c|c|c|c|c|}
\hline Group (n) & I (30) & II (20) & IIII (25) & IV (15) & $\mathrm{V}(15)$ & $p$ value \\
\hline $\mathrm{Hgb}$ & $10.83 \pm 1.32$ & $8.43 \pm 1.54$ & $9.67 \pm 1.46$ & $8.26 \pm 0.74$ & $8.65 \pm 1.63$ & 0.000 \\
\hline WBCs & $7.25 \pm 1.53$ & $7.38 \pm 1.56$ & $8.45 \pm 1.24$ & $8.16 \pm 1.37$ & $8.84 \pm 1.74$ & 0.002 \\
\hline PLT & $194.75 \pm 83.56$ & $185.54 \pm 74.33$ & $188.52 \pm 72.23$ & $198.87 \pm 63.59$ & $233.82 \pm 75.93$ & 0.364 \\
\hline PT & $12 \pm 0.09$ & $12.14 \pm 0.35$ & $12.10 \pm 0.21$ & $12.25 \pm 0.47$ & $12.34 \pm 0.36$ & 0.004 \\
\hline PTT & $30.41 \pm 2.65$ & $33.65 \pm 3.71$ & $32.26 \pm 4.42$ & $35.25 \pm 3.86$ & $35.55 \pm 4.52$ & 0.000 \\
\hline INR & $1.00 \pm 0.12$ & $1.14 \pm 0.14$ & $1.12 \pm 0.13$ & $1.21 \pm 0.05$ & $1.23 \pm 0.07$ & 0.000 \\
\hline ALT & $22.0 \pm 5.76$ & $24.00 \pm 7.36$ & $23.0 \pm 8.39$ & $25.0 \pm 8.85$ & $25.0 \pm 9.88$ & 0.667 \\
\hline AST & $30.0 \pm 6.67$ & $33.0 \pm 6.38$ & $32.0 \pm 7.27$ & $33.0 \pm 6.53$ & $34.0 \pm 7.46$ & 0.342 \\
\hline T. bil. & $0.84 \pm 0.23$ & $1.21 \pm 0.67$ & $0.86 \pm 0.43$ & $0.89 \pm 0.75$ & $1.02 \pm 0.13$ & 0.068 \\
\hline D. bil. & $0.17 \pm 0.06$ & $0.33 \pm 0.18$ & $0.18 \pm 0.15$ & $0.27 \pm 0.23$ & $0.48 \pm 0.25$ & 0.000 \\
\hline S. alb. & $4.23 \pm 0.44$ & $3.84 \pm 0.35$ & $4.12 \pm 0.51$ & $3.86 \pm 0.52$ & $3.92 \pm 0.65$ & 0.027 \\
\hline S. cr. & $0.8 \pm 0.10$ & $0.9 \pm 0.14$ & $0.87 \pm 0.12$ & $0.92 \pm 0.11$ & $0.98 \pm 0.12$ & 0.000 \\
\hline Bl. urea & $26.52 \pm 5.41$ & $30.0 \pm 6.82$ & $28.6 \pm 4.71$ & $32.45 \pm 5.83$ & $31.36 \pm 5.78$ & 0.008 \\
\hline
\end{tabular}

T. bil.: Total bilirubin, D. bil.: Direct bilirubin, S. alb.: Serum albumin, S. cr.: Serum creatinine, BI. urea: Blood urea

Table 3: History of other associated diseases

\begin{tabular}{llllllll}
\hline Group $(\mathrm{n})$ & & $\mathrm{I}(30)$ & $\mathrm{II}(20)$ & $\mathrm{III}(25)$ & $\mathrm{IV}(15)$ & $\mathrm{V}(15)$ & $\mathrm{p}$ value \\
\hline DM & $\mathrm{n}$ & 3 & 12 & 8 & 9 & 11 & 0.0276 \\
& $\%$ & 10 & 60 & 32 & 60 & 73.33 & \\
HTN & $\mathrm{n}$ & 6 & 16 & 17 & 13 & 15 & 0.037 \\
\multirow{2}{*}{ Cardiac } & $\%$ & 20 & 80 & 68 & 86.66 & 100 & \\
& $\mathrm{n}$ & 3 & 4 & 8 & 15 & 15 & 0.000 \\
& $\%$ & 10 & 20 & 32 & 100 & 100 & \\
\hline
\end{tabular}

DM: Diabetes mellitus, HTN: Hypertension.

Regarding the medical history of the patients, being diabetic or hypertensive or cardiac patient was statistically significant (Table 3).

Our studied patients were presented by NVUGIB, which was either in the form of hematemesis or melena or both together and was the statistically significant symptom $(p=0.011)$ as shown in Table 4.

Regarding the management of NVUGIB, UGI endoscopy had been performed and the results of the endoscopy are shown in Figure 3 and Table 5, which showed no statistical significance.

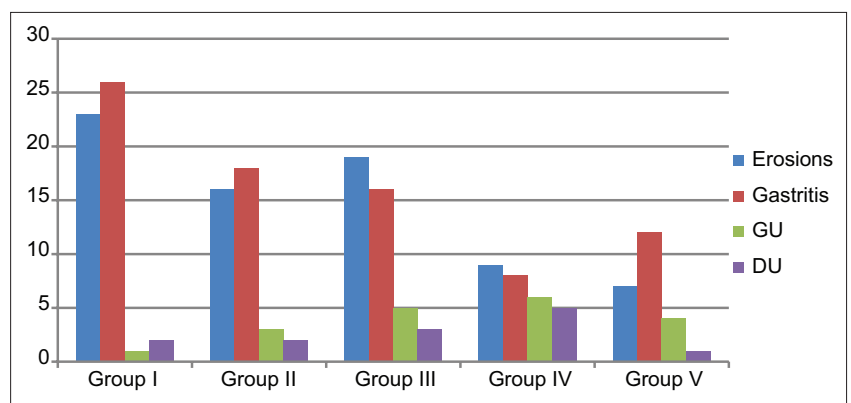

Figure 3: Upper gastrointestinal endoscopic findings of our studied patients

According to the management of UGIB, the need for blood transfusion was statistically significant when compared to the studied groups (no need to blood transfusion among the studied groups, $p=0.001$ and the need to blood transfusion among the studied groups, $p=0.003$ ), as shown in Table 6 and Figure 4 .

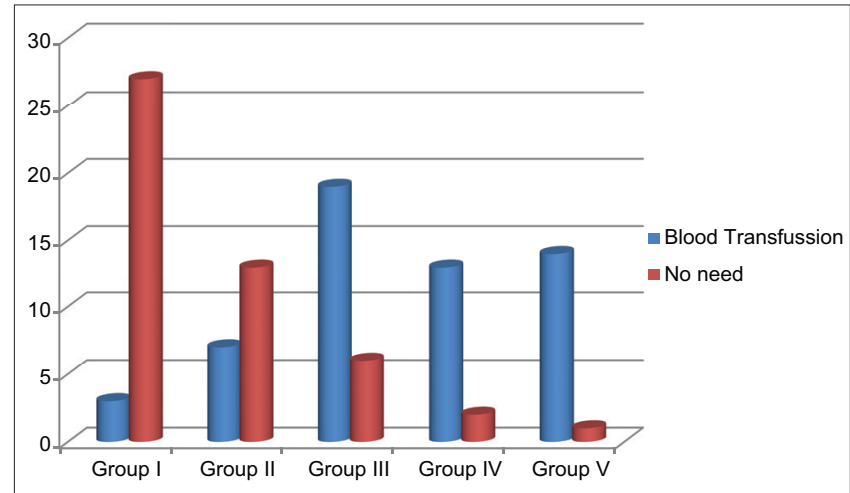

Figure 4: Need for blood transfusion in the management of our studied groups

Then, we followed up our studied patients after 6 and 12 months after the first attack of NVUGIB and the discharge from the hospital. We followed up the rebleeding episodes and occurrence of mortality while using their medications, we noticed statistically significant values among the studied patients' groups, as illustrated in Table 7.

\section{Discussion}

GI bleeding is a serious problem, especially in the elderly and/or multimorbid patients. On the one hand, any anticoagulant and antiplatelet treatment should be discontinued to help stopping the acute bleeding. On the other hand, discontinuing this type of therapy can significantly increase the risk for cardiovascular or cerebrovascular complications due to the underlying disease [44].

Table 4: Presenting bleeding symptoms

\begin{tabular}{|c|c|c|c|c|c|c|c|c|c|c|}
\hline \multicolumn{2}{|l|}{ Group } & I(30) & II (20) & III (25) & IV (15) & $\mathrm{V}(15)$ & $\chi^{2}$ & $p$ value & $\chi^{2}$ & $p$ value \\
\hline Hematemesis & $\mathrm{n}$ & 22 & 11 & 17 & 6 & 5 & 2.756 & 0.599 & 21.412 & 0.044 \\
\hline & $\%$ & 73.33 & 55 & 68 & 40 & 33.33 & & & & \\
\hline Melena & $\mathrm{n}$ & 7 & 4 & 6 & 3 & 2 & 0.535 & 0.970 & & \\
\hline & $\%$ & 23.33 & 20 & 24 & 20 & 13.33 & & & & \\
\hline Hematemesis and melena & $\begin{array}{l}\mathrm{n} \\
\%\end{array}$ & $\begin{array}{l}1 \\
3.33\end{array}$ & $\begin{array}{l}5 \\
25\end{array}$ & $\begin{array}{l}2 \\
8\end{array}$ & $\begin{array}{l}6 \\
40\end{array}$ & $\begin{array}{l}8 \\
53.33\end{array}$ & 13.03 & 0.011 & & \\
\hline
\end{tabular}


Table 5: UGI endoscopic findings of our studied patients

\begin{tabular}{llllllll}
\hline Group number & $\mathrm{I}(30)$ & $\mathrm{II}(20)$ & $\mathrm{III}(25)$ & $\mathrm{IV}(15)$ & $\mathrm{V}(15)$ & $\chi^{2}$ & $\mathrm{p}$ value \\
\hline Esophageal erosions & 23 & 16 & 19 & 9 & 7 & 1.265 & 0.867 \\
Gastritis & 26 & 18 & 16 & 8 & 12 & 1.479 & 0.830 \\
GU & 1 & 3 & 5 & 6 & 4 & 6.952 & 0.138 \\
DU & 2 & 2 & 3 & 5 & 1 & 5.188 & 0.268 \\
\hline GU: Gastric ulcer, DU: Duodenal ulcer. & & & & & &
\end{tabular}

Monotherapy with antiplatelet agents or anticoagulants is associated with an increasing risk of UGIB [45]. Therefore, these medications in patients with UGIB should be discontinued for days, even weeks, and during and after bleeding episode [46].

Table 6: Need for blood transfusion in the management of NVUGIB

\begin{tabular}{llllllllll}
\hline Group number & $\mathrm{I}(30)$ & $\mathrm{II}(20)$ & $\mathrm{III}(25)$ & $\mathrm{IV}(15)$ & $\mathrm{V}(15)$ & $\chi^{2}$ & $\mathrm{p}$ value & $\chi^{2}$ & $\mathrm{p}$ value \\
\hline No need & 27 & 13 & 6 & 2 & 1 & 17.419 & 0.001 & 46.835 & 0 \\
$\%$ & 90 & 65 & 24 & 13.33 & 6.66 & & & & \\
Need & 3 & 7 & 19 & 13 & 14 & 15.906 & 0.003 & & \\
$\%$ & 10 & 35 & 76 & 86.66 & 93.33 & & & & \\
\hline
\end{tabular}

Although the continuation of low-dose aspirin will increase the risk of rebleeding, it has been reported to be able to reduce all causes of mortality rate in a small sample of patients [47].

Table 7: Rebleeding and mortality after 6 months and 12 months

\begin{tabular}{lllllll}
\hline Group & $\mathrm{I}(30)$ & $\mathrm{II}(20)$ & III (25) & IV (15) & V (15) & p value \\
\hline Rebleeding after 6 months & & & & & & \\
$\quad$ Yes & 1 & 3 & 4 & 5 & 5 & 0.046 \\
$\quad$ No & 29 & 17 & 21 & 10 & 10 & \\
$\quad \begin{array}{l}\text { Mortality after 6 months } \\
\quad \text { Yes }\end{array}$ & 0 & 1 & 0 & 1 & 3 & 0.032 \\
$\quad$ No & 30 & 19 & 25 & 14 & 12 & \\
$\begin{array}{l}\text { Rebleeding after 12 months } \\
\quad \text { Yes }\end{array}$ & 1 & 3 & 2 & 4 & 6 & 0.046 \\
$\quad$ No & 29 & 17 & 22 & 11 & 9 & \\
$\begin{array}{l}\text { Mortality after 12 months } \\
\text { Yes }\end{array}$ & 0 & 1 & 0 & 1 & 4 & 0.032 \\
$\quad$ No & 30 & 19 & 25 & 14 & 11 & \\
\hline
\end{tabular}

The current evidence on the effects of aspirin or anticoagulants on the clinical outcomes of patients with UGIB is controversial, as Sung et al. [47] have reported that aspirin decreases the mortality of patients while Ortiz et al. [48] have suggested that these drugs have no effects. Similarly, conflicting results on the effects of anticoagulants such as warfarin have been reported [49].

In this study, we aimed to determine the impact of antiplatelets (aspirin) and anticoagulants on the clinical outcomes of 105 patients (53 males and 52 females) aged $36-62$ years. Forty-three were diabetic patients, 45 patients were cardiac, and 67 patients were hypertensive; 38 patients used NSAIDS and 29 of them used non-selective NSAIDS and 8 patients used selective NSAIDS who were hospitalized due to NVUGIB and followed up after 6 and 12 months for rebleeding attacks and mortality outcomes.

Statistically significant differences were found among the studied patients regarding age, history of associated disease (especially, cardiac), use of analgesics, clinical presentation of NVUGIB (both hematemesis and melena presenting together), $\mathrm{HB}$, WBCs, bleeding profile, kidney function, serum albumin, need for blood transfusion, rebleeding after 6 and 12 months, and mortality, these results are in conformity with Hearnshaw et al. [50] and Modaber et al. [51].
Aging and comorbidities are known predictors of mortality and adverse clinical outcomes [46]. The mortality rate in elderly patients with NVUGIB is increased and the reason is unclear, it may be due to that elderly patients are more prone to have complex comorbidities and be more susceptible to physiological changes associated with acute bleeding episodes than younger patients. Therefore, more careful follow-up with intensive monitoring is needed in this population group following bleeding events.

In our study, we noticed that the patient group on aspirin only had a less mortality and rebleeding events were lower than in other patient groups. Similar protective effects of aspirin against UGIB-related deaths, besides, its cardiovascular benefits had been reported by Sung et al. [47] Wehbeh et al. [52], and Souk et al. [53] and also in a study that included both peptic and non-peptic ulcer patients [49].

On the contrary, Ahsberg et al. [54] have reported non-statistically significant association between aspirin use and mortality although those taking NSAIDs were included. In addition, recently, Luo et al. [55] found that the use of aspirin increases the risk of $1^{\text {st }}$ time NVUGIB in general population after adjusting for age, gender, $H$. pylori infection, underlying comorbidities, and concomitant use of certain medications. Moreover, Taha et al. [56] noticed that a low-dose aspirin intake is associated with longer hospital stays and increased requirements of blood transfusion, but the study included those with variceal bleeding. However, Taha et al. [57] stated that in NVUGIB, the antiplatelet and anticoagulant activities are associated with older age and greater need for admission, transfusion, and rebleeding. The outcomes were more in users of anticoagulants even after adjustment for age, sex, and endoscopy, but with an insignificant effect on mortality.

Aspirin use was a predictor for short length of hospital stay in our study, which is consistent with a better overall outcome for those patients. This is different from what has been reported, which might be due to varied study designs [47] or the patients included in the study (both peptic ulcer disease [PUD] and nonPUD-related UGIB) [48].

On the other hand, Lanas et al. [49] observed that anticoagulants use to increase the requirements for blood transfusion and are associated with a longer hospital stay. Marmo et al. [4] showed that heparin, but not warfarin, increases mortality risk.

In our studied patients groups, we noticed that the most common cause of NVUGIB by endoscopy was gastritis followed by esophageal erosions then GU, but all with no statistically significant difference. This was not in agreement with Telaku et al. [58] who stated that the most common cause of NVUGIB was peptic ulcer.

Rebleeding is a predictor of mortality [50]. Rubin et al. [59] have suggested that the risk of rebleeding is not affected by antithrombotic. However, aspirin continuation seems to be associated with its increased risk of rebleeding. 
Non-bleeding related causes accounted for most deaths, which is in accordance with Wong et al. [60] who concluded that the number of patients who died of acute renal failure in their study was high enough to be considered as an independent risk factor of death [60], while we considered as a part of multiorgan failure.

Malignancies were also responsible for the non-bleeding-related deaths which were observed during follow-up periods. That was in agreement with the results of Marmo et al. [61], while cardiovascular causes were high [61].

\section{Conclusion}

Our study suggested that aspirin intake may be associated with less favorable clinical outcomes in UGIB, while combined anticoagulants and antiplatelet seem to be associated with worse clinical outcomes.

\section{Recommendations}

Study a larger scale of patients in many centers to decrease the bias.

Patients on low-dose ASA should be tested for H. pylori.

- A discussion and ultimately a consensus among gastroenterologists and cardiologists with respect to the benefit-risk ratios are desirable.

Adding a questionnaire to assess the quality of life before and after being admitted and endoscopically and medically managed during the episode of NVUGIB.

\section{Limitations}

Our study has some limitations and pitfalls:

- $\quad$ The small number of studied patients as we selected the patients with an emergency presentation (hematemesis and/or melena) and need to follow them up for a long time, which can be avoided if the study was retrospective.

- $\quad$ H. pylori analysis for the studied patients with NVUGIB which was not performed.

- $\quad$ Lack of endoscopic scoring system.

\section{Acknowledgment}

We would like to thank Dr. Hany Aly, Assistant Professor of Gastroenterology at Ain Shams University
Hospitals, for his effort in performing UGI endoscopy to our studied patients.

\section{References}

1. Hermansson M, Ekedahl A, Ranstam J, Zilling T. Decreasing incidence of peptic ulcer complications after the introduction of the proton pump inhibitors, a study of the Swedish population from 1974-2002. BMC Gastroenterol. 2009;9:25. https://doi. org/10.1186/1471-230x-9-25

PMid:19379513

2. Loperfido S, Baldo V, Piovesana E, Bellina L, Rossi K, Groppo M, et al. Changing trends in acute upper-GI bleeding: A populationbased study. Gastrointest Endosc. 2009;70(2):212-24. https:// doi.org/10.1016/j.gie.2008.10.051

PMid:19409558

3. Kim SY, Hyun JJ, Jung SW, Lee SW. Management of nonvariceal upper gastrointestinal bleeding. Clin Endosc. 2012;45(3):220-3. https://doi.org/10.5946/ce.2012.45.3.220 PMid:22977806

4. Marmo R, Koch M, Cipolletta L, Capurso L, Grossi E, Cestari R, et al. Predicting mortality in non-variceal upper gastrointestinal bleeders: Validation of the Italian PNED score and prospective comparison with the rockall score. Am J Gastroenterol. 2010;105(6):1284-91. https://doi.org/10.1038/ajg.2009.687 PMid:20051943

5. Biecker E, Heller J, Schmitz V, Lammert F, Sauerbruch T. Diagnosis and management of upper gastrointestinal bleeding. Dtsch Arztebl Int. 2008;105(5):85-94. https://doi.org/10.3238/ arztebl.2008.0085 PMid:19633792

6. NICE Clinical Guideline: Acute Upper Gastrointestinal Bleeding Management; 2015. Available from: http://www.guidance.nice. org.uk/cg. [Last accessed on 2019 May 11].

7. British Society of Gastroenterology Endoscopy Committee, Palmer KR. Non-variceal upper gastrointestinal haemorrhage: Guidelines. Gut. 2002;51(Suppl 4):iv1-6. PMid:12208839

8. Biecker E. Diagnosis and therapy of non-variceal upper gastrointestinal bleeding. World J Gastrointest Pharmacol Ther. 2015;6(4):172-82. https://doi.org/10.4292/wjgpt.v6.i4.172 PMid:26558151

9. Barkun AN, Bardou M, Kuipers EJ, Sung J, Hunt RH, Martel M, et al. International consensus recommendations on the management of patients with nonvariceal upper gastrointestinal bleeding. Ann Intern Med. 2010;152(2):101-13 PMid:20083829

10. Laine L, Jensen DM. Management of patients with ulcer bleeding. Am J Gastroenterol. 2012;107(3):345-60. PMid:22310222

11. Sreedharan A, Martin J, Leontiadis GI, Dorward S, Howden CW, Forman D, et al. Proton pump inhibitor treatment initiated prior to endoscopic diagnosis in upper gastrointestinal bleeding. Cochrane Database Syst Rev. 2010;7:CD005415. https://doi. org/10.1002/14651858.cd005415.pub2 PMid:20614440

12. Sachar H, VaidyaK, Laine L. Intermittent vs continuous proton pump inhibitor therapy for high-risk bleeding ulcers: A systematic review and meta-analysis. JAMA Intern Med. 2014;174(11):1755-62. https://doi.org/10.1001/jamainternmed.2014.4056 


\section{PMid:25201154}

13. Yuan $\mathrm{Y}$, Wang $\mathrm{C}$, Hunt $\mathrm{RH}$. Endoscopic clipping for acute nonvariceal upper-GI bleeding: A meta-analysis and critical appraisal of randomized controlled trials. Gastrointest Endosc. 2008;68(2):339-51. https://doi.org/10.1016/j.gie.2008.03.1122 PMid: 18656600

14. Brullet E, Campo R, Calvet X, Guell M, Garcia-Monforte N, Cabrol J. A randomized study of the safety of outpatient care for patients with bleeding peptic ulcer treated by endoscopic injection. Gastrointest Endosc. 2004;60(1):15-21. https://doi. org/10.1016/s0016-5107(04)01314-8 PMid:15229419

15. Lau JY, Sung JJ, Lee KK, Yung MY, Wong SK, Wu JC, et al. Effect of intravenous omeprazole on recurrent bleeding after endoscopic treatment of bleeding peptic ulcers. N Engl J Med. 2000;343(5):310-6. https://doi.org/10.1056/ nejm200008033430501

PMid: 10922420

16. Zargar SA, Javid G, Khan BA, Yattoo $G N$, Shah $A H$, Gulzar GM, et al. Pantoprazole infusion as adjuvant therapy to endoscopic treatment in patients with peptic ulcer bleeding: Prospective randomized controlled trial. J Gastroenterol Hepatol. 2006;21(4):716-21. https://doi. org/10.1111/j.1440-1746.2006.04292.x

PMid:16677158

17. Barkun AN, Herba K, Adam V, Kennedy W, Fallone CA, Bardou M. High-dose intravenous proton pump inhibition following endoscopic therapy in the acute management of patients with bleeding peptic ulcers in the USA and Canada: A cost-effectiveness analysis. Aliment Pharmacol Ther. 2004;19(5):591-600. https://doi.org/ 10.1046/j.1365-2036.2004.01808.x PMid: 14987328

18. Lee KK, You JH, Wong IC, Kwong SK, Lau JY, Chan TY, et al. Cost-effectiveness analysis of high-dose omeprazole infusion as adjuvant therapy to endoscopic treatment of bleeding peptic ulcer. Gastrointest Endosc. 2003;57(2):160-4. https://doi. org/10.1067/mge.2003.74

PMid:12556776

19. Laine L, Peterson WL. Bleeding peptic ulcer. N Engl J Med. 1994;331(11):717-27. https://doi.org/10.1056/ nejm199409153311107

PMid:8058080

20. Lau JY, Sung JJ, Lam YH, Chan AC, Ng EK, Lee DW, et al. Endoscopic retreatment compared with surgery in patients with recurrent bleeding after initial endoscopic control of bleeding ulcers. N Engl J Med. 1999;340(10):751-6. https://doi. org/10.1056/nejm199903113401002

PMid:10072409

21. Ripoll $C$, Bañares $R$, Beceiro I, Menchén $P$, Catalina MV, Echenagusia $A$, et al. Comparison of transcatheter arterial embolization and surgery for treatment of bleeding peptic ulcer after endoscopic treatment failure. J Vasc Interv Radiol. 2004;15(5):447-50. https://doi.org/10.1097/01. rvi.0000126813.89981.b6 PMid: 15126653

22. Sung JJ, Chung SC, Ling TK, Yung MY, Leung VK, Ng EK et al. Antibacterial treatment of gastric ulcers associated with Helicobacter pylori. N Engl J Med. 1995;332(3):139-42. https:// doi.org/10.1056/nejm199501193320302

PMid:7800005

23. Udd M, Miettinen P, Palmu A, Julkunen R. Effect of shortterm treatment with regular or high doses of omeprazole on the detection of Helicobacter pylori in bleeding peptic ulcer patients. Scand J Gastroenterol. 2003;38(6):588-93. https://doi. org/10.1016/s0016-5085(03)80873-9

\section{PMid: 12825865}

24. Chan FK, Hung LC, Suen BY, Wu JC, Lee KC, Leung VK, et al. Celecoxib versus diclofenac and omeprazole in reducing the risk of recurrent ulcer bleeding in patients with arthritis. N Engl J Med. 2002;347:2104-10. https://doi.org/10.1056/nejmoa021907 PMid:12501222

25. Chan FK, Wong VW, Suen BY, Wu JC, Ching JY, Hung LC, et al. Combination of a cyclo-oxygenase-2 inhibitor and a proton-pump inhibitor for prevention of recurrent ulcer bleeding in patients at very high risk: A double-blind, randomised trial. Lancet. 2007;369(9573):1621-6. https://doi.org/10.1016/ s0739-5930(08)79176-1

\section{PMid:17499604}

26. Scheiman JM, Yeomans ND, Talley NJ, Vakil N, Chan FK, Tulassay Z, et al. Prevention of ulcers by esomeprazole in at-risk patients using non-selective NSAIDs and COX-2 inhibitors. Am J Gastroenterol. 2006;101(4):701-10. https://doi. org/10.1111/j.1572-0241.2006.00499.x

\section{PMid: 16494585}

27. Hamm CW, Bassand JP, Agewall S, Bax J, Boersma E, Bueno $\mathrm{H}$, et al. ESC Guidelines for the management of acute coronary syndromes in patients presenting without persistent ST-segment elevation: The Task Force for the management of acute coronary syndromes (ACS) in patients presenting without persistent ST-segment elevation of the European Society of Cardiology (ESC). Eur Heart J. 2011;32(23):2999-3054. https:// doi.org/10.12968/bjca.2011.6.11.547

PMid:21873419

28. Hurlen M, Abdelnoor M, Smith P, Erikssen J, Arnesen H. Warfarin, aspirin, or both after myocardial infarction. N Engl J Med. 2002;347(13):969-74. https://doi.org/10.1056/nejmoa020496 PMid: 12324552

29. Rothberg MB, Celestin C, Fiore LD, Lawler E, Cook JR. Warfarin plus aspirin after myocardial infarction or the acute coronary syndrome: Meta-analysis with estimates of risk and benefit. Ann Intern Med. 2005;143(4):241-50. https://doi. org/10.7326/0003-4819-143-4-200508160-00005 PMid:16103468

30. Sørensen R, Hansen ML, Abildstrom SZ, Hvelplund A, Andersson C, Jørgensen C, et al. Risk of bleeding in patients with acute myocardial infarction treated with different combinations of aspirin, clopidogrel, and vitamin $\mathrm{K}$ antagonists in Denmark: A retrospective analysis of nationwide registry data. Lancet. 2009;374(9706):1967-74. https://doi.org/10.1016/ s0140-6736(09)61751-7

PMid:20006130

31. Targownik LE, Nabalamba A. Trends in management and outcomes of acute nonvariceal upper gastrointestinal bleeding: 1993-2003. Clin Gastroenterol Hepatol. 2006;4(12):1459-66. https://doi.org/10.1016/j.cgh.2006.08.018 PMid:17101296

32. Strate LL. Lower GI bleeding: Epidemiology and diagnosis. Gastroenterol Clin North Am. 2005;34(4):643-64. PMid: 16303575

33. van Leerdam ME, Vreeburg EM, Rauws EA, Geraedts AA, Tijssen JG, Reitsma JB, et al. Acute upper GI bleeding: Did anything change? Time trend analysis of incidence and outcome of acute upper GI bleeding between 1993/1994 and 2000. Am J Gastroenterol. 2003;98(7):1494-9. https://doi. org/10.1111/j.1572-0241.2003.07517.x PMid: 12873568

34. Nutescu EA, Shapiro NL, Chevalier A, Amin AN. A pharmacologic overview of current and emerging anticoagulants. Cleve Clin J Med. 2005;72(Suppl 1):S2-6. https://doi.org/10.3949/ccjm.72. suppl_1.s2 


\section{PMid: 15853173}

35. Camm AJ, Lip GY, De Caterina R, Savelieva I, Atar D, Hohnloser SH, et al. 2012 focused update of the ESC Guidelines for the management of atrial fibrillation: An update of the 2010 ESC Guidelines for the management of atrial fibrillation developed with the special contribution of the European Heart Rhythm Association. Europace. 2012;14(10):1385-413. https:// doi.org/10.3410/f.718304414.793499785

\section{PMid:22923145}

36. Jennings LK. Role of platelets in atherothrombosis. Am J Cardiol. 2009;103(Suppl 3):4A-10.

PMid:19166707

37. Muñoz-Esparza C, Jover E, Hernández-Romero D, Saura D, Valdés M, Lip GY, et al. Interactions between clopidogrel and proton pump inhibitors: A review of evidence. Curr Med Chem. 2011;18(16):2386-400. https://doi.org/10.2174/ 092986711795843245

\section{PMid:21568918}

38. Ho PM, Maddox TM, Wang L, Finn SD, Jesse RL, Peterson ED, et al. Risk of adverse outcomes associated with concomitant use of clopidogrel and proton pump inhibitors following acute coronary syndrome. JAMA. 2009;301(9):937-44. https://doi. org/10.1001/jama.2009.261

PMid:19258584

39. Juurlink DN, Gomes T, Ko DT, Szmitko PE, Austin PC, Tu JV, et al. A population-based study of the drug interaction between proton pump inhibitors and clopidogrel. CMAJ. 2009;180(7):7138. https://doi.org/10.1503/cmaj.082001

PMid:19176635

40. Moayyedi P, Sadowski DC. Proton pump inhibitors and clopidogrel - hazardous drug interaction or hazardous interpretation of data? Can J Gastroenterol. 2009;23(4):251-2. https://doi.org/10.1155/2009/868946

PMid:19373416

41. Melloni C, Washam JB, Jones WS, Halim SA, Hasselblad V, Mayer SB, et al. Conflicting results between randomized trials and observational studies on the impact of proton pump inhibitors on cardiovascular events when coadministered with dual antiplatelet therapy: Systematic review. Circ Cardiovasc Qual Outcomes. 2015;8(1):47-55. https://doi.org/10.1161/ circoutcomes.114.001177

PMid:25587094

42. Dunn SP, Steinhubl SR, Bauer D, Charnigo RJ, Berger PB, Topol EJ. Impact of proton pump inhibitor therapy on the efficacy of clopidogrel in the CAPRIE and CREDO trials. J Am Heart Assoc. 2013;2(1):e004564. https://doi.org/10.1161/ jaha.112.004564

PMid:23525436

43. Simon T, Verstuyft C, Mary-Krause M, Quteineh L, Drouet E, Méneveau N, et al. Genetic determinants of response to clopidogrel and cardiovascular events. $N$ Engl J Med. 2009;360(4):363-75. https://doi.org/10.1056/nejmoa0808227 PMid:19106083

44. Gutermann IK, Niggemeier V, Zimmerli LU, Holzer BM, Battegay E, Scharl M. Gastrointestinal bleeding and anticoagulant or antiplatelet drugs: Systematic search for clinical practice guidelines. Medicine (Baltimore). 2015;94(1):e377. https://doi.org/10.1097/md.0000000000000377 PMid:25569664

45. García Rodríguez LA, Lin KJ, Hernández-Díaz S, Johansson S Risk of upper gastrointestinal bleeding with low-dose acetylsalicylic acid alone and in combination with clopidogrel and other medications. Circulation. 2011;123(10):1108-15. https://doi.org/10.1161/circulationaha.110.973008

PMid:21357821
46. Sostres C, Lanas A. Should prophylactic low-dose aspirin therapy be continued in peptic ulcer bleeding? Drugs. 2011;71(1):1-10. https://doi.org/10.2165/11585320-000000000-00000 PMid:21175237

47. Sung JJ, Lau JY, Ching JY, Wu JC, Lee YT, Chiu PW, et al. Continuation of low-dose aspirin therapy in peptic ulcer bleeding: A randomized trial. Ann Intern Med. 2010;152(1):1-9. https://doi. org/10.7326/0003-4819-152-1-201001050-00179 PMid:19949136

48. Ortiz V, Ortuño J, Rodríguez-Soler M, Iborra M, Garrigues V, Ponce J. Outcome of non-variceal acute upper gastrointestinal bleeding in patients with antithrombotic therapy. Digestion. 2009;80(2):89-94. https://doi.org/10.1159/000219345 PMid:19828953

49. LanasA,AabakkenL,FonsecaJ, MunganZA,PapatheodoridisGV, Piessevaux $\mathrm{H}$, et al. Clinical predictors of poor outcomes among patients with nonvariceal upper gastrointestinal bleeding in Europe. Aliment Pharmacol Ther. 2011;33(11):1225-33. https:// doi.org/10.1111/j.1365-2036.2011.04651.x

PMid:21480935

50. Hearnshaw SA, Logan RF, Lowe D, Travis SP, Murphy MF, Palmer KR. Acute upper gastrointestinal bleeding in the UK: Patient characteristics, diagnoses and outcomes in the 2007 UK audit. Gut. 2011;60(10):1327-35. https://doi.org/10.1136/ gut.2010.228437

PMid:21490373

51. Modaber AA, Hammad A, Aliyev V. Effects of aspirin and anticoagulants on morbidity and mortality in patients with non-variceal upper gastrointestinal bleeding. Int $\mathrm{J}$ Hepatol Gastroenterol. 2017;3(3):71-8.

52. Wehbeh A, Tamim HM, Abu Daya H, Abou Mrad R, Badreddine RJ, Eloubeidi MA, et al. Aspirin has a protective effect against adverse outcomes in patients with nonvariceal upper gastrointestinal bleeding. Dig Dis Sci. 2015;60(7):2077-87. https://doi.org/10.1007/s10620-015-3604-1

PMid:25732717

53. Souk KM, Tamim HM, Abu Daya HA, Rockey DC, Barada KA Aspirin use for primary prophylaxis: Adverse outcomes in nonvariceal upper gastrointestinal bleeding. World J Gastrointest Surg. 2016;8(7):501-7. https://doi.org/10.4240/wjgs.v8.i7.501 PMid:27462392

54. Ånsberg K, Höglund P, Staël von Holstein C. Mortality from peptic ulcer bleeding: The impact of comorbidity and the use of drugs that promote bleeding. Aliment Pharmacol Ther. 2010;32(6):801-10. https://doi.org/10.1111/j.1365-2036.2010.04399.x PMid:20653635

55. Luo $\mathrm{PJ}$, Lin $\mathrm{XH}$, Lin $\mathrm{CC}$, Luo JC, Hu HY, Ting $\mathrm{PH}$, et al. Risk factors for upper gastrointestinal bleeding among aspirin users: An old issue with new findings from a population-based cohort study. J Formos Med Assoc. 2019;118(5):939-44. https://doi. org/10.1016/j.jfma.2018.10.007

PMid:30366771

56. Taha AS, Angerson WJ, Knill-Jones RP, Blatchford O. Clinical outcome in upper gastrointestinal bleeding complicating low-dose aspirin and antithrombotic drugs. Aliment Pharmacol Ther. 2006;24(4):633-6. https://doi. org/10.1111/j.1365-2036.2006.03017.x PMid:16907895

57. Taha A, McCloskey C, CraigenT CC, Angerson W Antiplatelet versus anticoagulant effects in non-variceal upper gastrointestinal bleeding. Gut. 2019;68(Suppl 2):A1-269. https:// doi.org/10.1016/s0016-5085(19)38792-x

58. Telaku S, Kraja B, Qirjako G, Prifti S, Fejza H. Clinical outcomes of nonvariceal upper gastrointestinal bleeding in Kosova. Turk J Gastroenterol. 2014;25(Suppl 1):110-5. https://doi.org/10.5152/ 
tjg.2014.4351
PMid:2591028

59. Rubin TA, Murdoch M, Nelson DB. Acute GI bleeding in the setting of supratherapeutic international normalized ratio in patients taking warfarin: Endoscopic diagnosis, clinical management, and outcomes. Gastrointest Endosc. 2003;58(3):369-73. https:// doi.org/10.1016/s0016-5107(03)00010-5

PMid:14528210

60. Wong GL, Wong VW, Chan Y, Ching JY, Au K, Hui AJ, et al. High incidence of mortality and recurrent bleeding in patients with Helicobacter pylori-negative idiopathic bleeding ulcers. Gastroenterology. 2009;137(2):525-31. https://doi. org/10.1053/j.gastro.2009.05.006

PMid:19445937

61. Marmo R, Koch M, Cipolletta L, Capurso L, Pera A, Bianco MA, et al. Predictive factors of mortality from nonvariceal upper gastrointestinal hemorrhage: A multicenter study. Am J Gastroenterol. 2008;103(7):1639-47.

PMid:18564127 